\section{Communication}

[Comunicação]
M. Fujimori

https://orcid.org/0000-0001-7790-9827

V.R.F. Sousa

https://orcid.org/0000-0001-6209-4514

\title{
Cytological and molecular detection of Leishmania spp. in different biological tissues of dogs in areas endemic for visceral leishmaniasis
}

\author{
[Detecção citológica e molecular de Leishmania spp. em diferentes amostras biológicas \\ de cães em áreas endêmicas para leishmaniose visceral] \\ A.F.L.R. Dias ${ }^{1}$, A.B.P.F. Almeida ${ }^{2}$, J.Y. Rodrigues ${ }^{3}$, L. Nakazato ${ }^{2}$, \\ M. Fujimori ${ }^{4}$, V.R.F. Sousa ${ }^{2}$

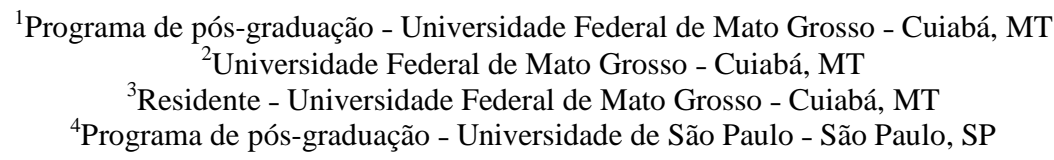

Leishmaniasis, a zoonotic disease caused by protozoa of the genus Leishmania, is a serious global public health problem. It is estimated that 1.3 million new cases and 20,000 to 30,000 deaths occur annually (Leishmaniasis, 2018). In the Americas, Brazil is the country with the highest occurrence rate of visceral leishmaniasis (VL), which is considered the most serious and fatal form of the disease caused by Leishmania (Leishmania) infantum (syn: L. (L.) chagasi), being transmitted by Lutzomyia longipalpis and L. cruzi species sandflies (Brasil, 2014).

As the main source of the vector infection, the dogs play an important role in the domestic transmission cycle of VL, which makes it essential to develop researches for canine visceral leishmaniasis (CanL). In this context, it is important to investigate the prevalence of the infection by methods of detection of Leishmaniaspecific antibodies (serology), DNA detection (PCR) or parasitological (cytology, histopathology, immunohistochemistry, culture) (Quaresma et al., 2009). These methods contribute to the epidemiological surveillance providing results to the Brazilian Ministry of Health, that propose specific measures of surveillance, prevention and control of the disease.
However, the distribution of CanL throughout Brazil's territory, its sympatric occurrence with other microorganisms, and the limitations of the sero-epidemiological studies can result in the occurrence of cross reaction with other phylogenetic similar species which underscore the need for the correct classification of parasites of the genus Leishmania (Coutinho et al., 2011). Thus, this study aimed to evaluate the occurrence of Leishmania spp. in dogs domiciled in an endemic region by parasitological and molecular techniques in different biological tissues.

A transversal study was conducted in the region of Baixada Cuiabana, Mato Grosso, Brazil. The investigation involved dogs of both sexes and different breeds, age $\geq 6$ months, from the municipalities Cuiabá $\left(15^{\circ} 35^{\prime} 56^{\prime \prime} \mathrm{S}\right.$ and 56 06'01'W), Várzea Grande (15³8'49”S and $\left.56^{\circ} 07^{\prime} 58^{\prime \prime} \mathrm{W}\right)$, and Santo Antônio de Leverger (15'51'56"S and 56 $\left.04^{\prime} 36^{\prime \prime} \mathrm{W}\right)$. This study was conducted in accordance with the ethical principles approved by the Ethics Committee on Animal Use (CEUA) of the Federal University of Mato Grosso under protocol number 23108.014950/11-5.

With the written approval of the owners, the dogs were sedated intramuscularly with ketamine $(10 \mathrm{mg} / \mathrm{kg})$ and acepromazine $(0.2 \mathrm{mg} / \mathrm{kg})$ to collect samples of blood, lymph nodes and bone

Recebido em 27 de abril de 2018

Aceito em 25 de janeiro de 2019

E-mail: alvaro.felipe.ufmt@gmail.com 
marrow aspirates by jugular venipuncture, popliteal lymph node puncture and sternal puncture, respectively. Immediately after sampling, the collected material was distributed to glass slides and cytology smears were stained with Romanowsky and analyzed under an optical microscope with 1000x magnification for observation of Leishmania amastigotes.

DNA extraction from clinical samples was done using phenol-chloroform method (Gomes et al., 2007). For Leishmania spp., the nPCR was performed with the external primers TRY927F (5'-GAAACAAGAAACACGGGAG-3') and TRY927R (5'-CTACTGGGCAGCTTGGA-3') and internal primers SSU561F (5'TGGGATAACAAAGGAGCA-3') and SSU561R (5'CTGAGACTGTAACCTCAAAGC-3'), amplifying a DNA fragment of $700 \mathrm{pb}$, corresponding to the 18S rRNA gene (Smith et al., 2008). To detect possible false-positive and false-negative reaction, samples of $L$. (L.) infantum (MHOMQ/GB/1994/PP75) DNA were used as positive control, and ultrapure water as negative control in all the reactions. DNA and amplification product quality and integrity were analyzed by electrophoresis in $1.5 \%$ agarose, stained with GelRed (Biotium, Hayward, CA, USA) and observed in ChemiDoc XRS ${ }^{+}$(Bio-rad Laboratories, Inc., Hercules, CA, USA) using the software Image Lab (Bio-rad Laboratories, Inc., Hercules, CA, USA).

Positive samples were purified with an Illustra GFX PCR DNA and Gel Band Purification Kit (GE Healthcare Bio-Sciences, USA) and sequenced on the automatic model ABI-PRISM $3500 \quad$ Genetic Analyzer. (Applied Biosystems/PerkinElmer, Foster City, CA). The sequences were deposited in GenBank database using the Basic Local Alignment Search Tool (BLAST) of the National Center for Biotechnology Information (NCBI) to confirm the specie of Leishmania. Statistical analyses were performed with the aid of Epi Info version 7 (Center for Disease Control and Prevention [CDC], Atlanta, GA, USA). The agreement between the techniques was investigated using the kappa $(k)$ test. The confidence interval employed in all statistical analyses was $95 \%$.

Of the 205 dogs evaluated, Leishmania DNA was detected in $34 \mathrm{dogs}$ (16.58\%), while $12 \mathrm{dogs}$ $(5.85 \%)$ were positive on the parasitological diagnosis. The overall prevalence detected by combining the cytological and molecular tests was $16.58 \%$ (34/205), being the highest infection rate found in the municipality of Cuiabá, followed by the municipalities of Várzea Grande and Santo Antônio de Leverger (Table 1).

Table 1. Cytological examination and nested PCR results of the investigation of Leishmania spp., in different biological samples obtained from 205 dogs residing in Baixada Cuiabana

\begin{tabular}{llllllll}
\hline \multirow{2}{*}{ City } & \multicolumn{2}{l}{ Parasitological diagnosis } & \multicolumn{3}{l}{$\mathrm{nPCR}^{\mathrm{a}}$} & \multirow{2}{*}{ Total $+/ n^{\mathrm{d}}$} \\
\cline { 2 - 6 } & $\mathrm{BM}^{\mathrm{a}}$ & $\mathrm{LN}^{\mathrm{b}}$ & $\mathrm{BL}^{\mathrm{c}}$ & $\mathrm{BM}^{\mathrm{a}}$ & $\mathrm{LN}^{\mathrm{b}}$ & $\mathrm{BL}^{\mathrm{c}}$ & \\
\hline Cuiabá & 0 & 0 & 0 & 4 & 7 & 2 & $11 / 50(22 \%)$ \\
Várzea Grande & 9 & 9 & 2 & 15 & 14 & 4 & $18 / 82(21,95 \%)$ \\
*Santo A. de Leverger & 1 & 1 & 1 & 1 & 5 & 1 & $5 / 73(6,84 \%)$ \\
\multirow{2}{*}{ Total $+/ n$} & $10 / 205$ & $10 / 205$ & $3 / 205$ & $20 / 205$ & $26 / 205$ & $7 / 205$ & $34 / 205$ \\
& $(4,87 \%)$ & $(4,87 \%)$ & $(1,46 \%)$ & $(9,75 \%)$ & $(12,68 \%)$ & $(3,41 \%)$ & $(16,58 \%)$ \\
\hline
\end{tabular}

* Santo Antônio de Leverger; ${ }^{\mathrm{a}}$ Bone marrow; ${ }^{\mathrm{b}}$ Lymph node; ${ }^{\mathrm{c}}$ Blood; ${ }^{\mathrm{d}}$ Positive in at least one clinical sample.

Sensitivity and specificity values were calculated separately for bone marrow, lymph node and blood nPCR technique, considering the direct parasitological examination as the gold standard, due to the possibility of visualizing the amastigotes forms. The results of sensitivity, specificity and Kappa coefficient by nPCR were for bone marrow $(94.87 \%, 100 \%, 0.643)$, lymph node $(91.8 \%, 100 \%, 0.522)$ and blood $(98 \%, 100 \%, 0.592)$, respectively.
The 53 amplified samples in the nPCR (GenBank accession number of KU948433 to KU948485) were similar to the 18S rRNA gene of L. infantum (XR_001203206. 1). The sequences presented little variation in the percentage of similarity with $L$. infantum: two samples had $87 \%$ and $88 \%$ similarity, two presented $89 \%$, three presented $91 \%$, 42 samples presented $99 \%$ and four samples showed $100 \%$ similarity. 
L. infantum is present and infecting the canine population of Baixada Cuiabana, representing a serious public health problem, since dogs constitute one of the main sources of the vector infection and play an important role in the ecology and epidemiology of this disease (Brasil, 2014). Previous studies conducted in Cuiabá and Várzea Grande reported prevalence of $22.1 \%$ (Almeida et al., 2012) and 23\% (Fujimori et al., 2016), similar results to those observed in this study. In relation to the municipality of Santo Antônio de Leverger, the prevalence of $10.85 \%$ found in serological survey (Unpublished dates; Souza, 2018; UFMT) was higher than that found in our study. According to Missawa and Borba (2009), several factors can be associated with different prevalence in the same municipality, including the area where the dogs reside, the technique used and the type of biological material analyzed.

Regarding the diagnostic methods, the parasitological test is routinely used for the diagnosis of CanL, however it is infeasible in epidemiological studies, due to low sensitivity. We observed that nPCR shows high sensitivity and specificity and although blood had higher sensitivity than other tissues, the proportion of positive results was lower, demonstrating the preference of the etiological agent for the host's mononuclear phagocytic system, resulting in lower parasite loads in the bloodstream (Laurenti, 2009). Several biological tissues can be used for the investigation of Leishmania spp., but there is still no consensus on what constitutes the best tissue sample, in this premise, we highlight bone marrow as the best biological tissue, that showed Kappa index greater than 0.643 , which represents a substantial agreement.
A neglected disease in Brazil, the occurrence of CanL and identification of the etiologic agent in the target areas of sero-epidemiological surveys are important, since the cross reactivity among other phylogenetic similar species, e.g., Leishmania spp. and Trypanosoma cruzi in canine infection has already been reported (Troncarelli et al., 2009). Furthermore, in 2013 the first case of canine $T$. cruzi infection was reported in Cuiabá, ratifying the importance of providing data for future epidemiological surveys (Almeida et al., 2013).

The 18S rRNA genomic region showed satisfactory results, molecularly characterizing the CanL. The simultaneous use of parasitological examination and nPCR allowed to identify the Leishmania species circulating in the region and to guarantee the correct diagnosis of CanL, reducing the occurrence of false negative and false positive results, frequently observed in sero-epidemiological studies. Although no other species of Leishmania was detected in this study, the investigation of different agents in endemic areas for VL is necessary, generating knowledge about the circulation of species in the region, since euthanasia is one of the control measures for CanL in Brazil (Brasil, 2014).

Causative agent of CanL is present in the region of Baixada Cuiabana. Complementary diagnostic, such as nPCR, showed great potential to detect and identify $L$. infantum. Bone marrow was considered the most adequate sample for the diagnosis of the disease.

Keyword: visceral canine leishmaniosis, Leishmania infantum, PCR, parasitology, Kalaazar

\section{RESUMO}

Devido à ampla distribuição da leishmaniose visceral (LV) no Brasil e à importância dos cães no ciclo de transmissão dessa zoonose, o presente estudo teve como objetivo avaliar a ocorrência de Leishmania spp. e caracterizar a espécie circulante em diferentes tecidos biológicos de cães da Baixada Cuiabana, Mato Grosso, Brasil. Amostras de sangue, linfonodo e medula óssea foram coletadas de 205 cães para realização de análise parasitológica por citologia e análise molecular por meio da nested PCR (nPCR) e do sequenciamento. Dos 205 cães estudados, 34 (16,58\%) animais foram positivos pela nPCR, dos quais 12 possuíam formas amastigotas de Leishmania spp. na citologia. Amostras positivas na nPCR foram sequenciadas e caracterizadas como Leishmania (Leishmania) infantum. A sensibilidade da nPCR nas amostras de medula óssea, linfonodo e sangue foi de 94,87\%, 91,8\% e 98\%, respectivamente, enquanto a especificidade foi de $100 \%$ para todas as amostras. O presente estudo relata a ocorrência de LV canina em 16,58\% dos cães analisados, caracterizando a L. infantum como agente causador. Entre as amostras 
avaliadas, a medula óssea foi a única a apresentar concordância substancial entre as técnicas de nPCR $e$ citologia $(k=0,643)$, sendo considerada a amostra mais adequada para o diagnóstico da doença. Os resultados ampliam o conhecimento de espécies de Leishmania infectando cães no Brasil, destacando a importância da identificação etiológica em áreas com escassos dados moleculares.

Palavras-chave: leishmaniose visceral canina, Leishmania infantum, PCR, parasitologia, Kala-azar

\section{REFERENCES}

ALMEIDA, A.B.P.F.; SOUSA, V.R.F.; CRUZ, F.A.C.S. et al. Canine visceral leishmaniasis: seroprevalence and risk factors in Cuiabá, Mato Grosso, Brazil. Rev. Bras. Parasitol. Vet., v. 21, p.359-365, 2012.

ALMEIDA, A.B.P.F.; PAULA, D.A.J.; OTTON, M.L.O. et al. Natural infection by Trypanosoma cruzi in one dog in central western Brazil: a case report. Rev. Inst. Med. Trop. São Paulo, v.55, p.1-3, 2013.

BRASIL. Ministério da Saúde. Manual de vigilância e controle da leishmaniose visceral., Brasília: Ministério da Saúde - Secretaria de Vigilância em Saúde, 2014. 122p.

COUTINHO, C.E.R.; SANTOS, D.O.; BAPTISTA, C. et al. Evaluation of Leishmania (Leishmania) chagasi strains isolated from dogs originating from two visceral leishmaniasisendemic areas in Brazil using multilocus enzyme electrophoresis. Rev. Soc. Bras. Med. Trop., v.44, p.572-575, 2011.

FUJIMORI, M.; ALMEIDA, A.B.P.F.; DIAS, A.F.L.R. et al. Prevalence and associated factors of canine visceral leishmaniasis in an endemic area of Mato Grosso, Brazil. Acta Sci. Vet., v.44, p.1-6, 2016.

GOMES, A.H.S.; FERREIRA, I.M.R.; LIMA, M.L.S.R. et al. PCR identification of Leishmania in diagnosis and control of canine leishmaniasis. Vet. Parasitol., v.144, p.234-241, 2007.
LAURENTI, M.D. Correlation between parasitological and serological diagnosis in canine American visceral leishmaniasis. Bol. Epidemiol. Paul., v.6, p.13-23, 2009.

MISSAWA, N.A.; BORBA, J.F. Leishmaniose visceral no município de Várzea Grande, estado de Mato Grosso, no período de 1998 a 2007. Rev. Soc. Bras. Med. Trop., v.42, p.496-502, 2009.

QUARESMA, P.F.; MURTA, S.M.F.; FERREIRA, E.C. et al. Molecular diagnosis of canine visceral leishmaniasis: Identification of Leishmania species by PCR-RFLP and quantification of parasite DNA by real-time PCR. Acta. Trop., v.111, p.289-294, 2009.

SMITH, A.; ClARK, P.; AVERIS, S. et al. Trypanosomes in a declining species of threatened Australian marsupial, the brush-tailed Bettongia penicillata (Marsupialia: Potoroidae). Parasitology, v.135, p.1329-1335, 2008.

TRONCARELLI, M.Z.; CAMARGO, J.B.; MACHADO, J.G. et al. Leishmania spp. and/or Trypanosoma cruzi diagnosis in dogs from endemic and nonendemic areas for canine visceral leishmaniasis. Vet. Parasitol., v.164, p.118-123, 2009.

LEISHMANIASIS. Geneva: World Health Organization, 2018. Available in: <http://www.who.int/leishmaniasis/en/>. Accessed in: 21 Nov. 2018. 